\title{
ADSORPTION OF Pb IONS FROM OILY WASTEWATER BY ANTHRAQUINONE MODIFIED CARBON NANOTUBE
}

\author{
Vahid Moghaddam Nansa1, Maryam Otadi ${ }^{2}{ }^{凶}$, Amir Heydarinasab $^{1}$, \\ Rahebeh Amiri ${ }^{3}$
}

https://doi.org/10.23939/chcht15.01.089

\begin{abstract}
The aim of this research was to investigate the adsorption properties of anthraquinone modified carbon nanotube (ACNT) in oily wastewaters containing $\mathrm{Pb}$ ions. The modified adsorbents were characterized using Fourier transform infra-red spectroscopy and SEM analysis. The adsorption and regeneration studies were conducted in batch mode using a Taguchi (L16) orthogonal array to optimize experimental runs. The controllable factors used in this study consisted of: $\mathrm{pH}$ of the solution (A); adsorbent dosage (B); adsorbent type (C); contact time (D); temperature (F). The effects of each factor were studied at four levels on the removal efficiency of metals from aqueous solution. Concentrations of metal ions were assessed by atomic absorption spectrometer. The total optimum adsorptive removal of lead ions was obtained with $C_{0}=10 \mathrm{mg} \cdot l^{-1}, T=338 \mathrm{~K}, \mathrm{pH}=6, m=0.020 \mathrm{mg}$ and $t=60 \mathrm{~min}$. The Langmuir model was representative to simulate adsorption isotherms. The adsorption kinetics of $\mathrm{Pb}$ adsorption by ACNT was modeled using the pseudofirst order, the pseudo-second order, and intraparticle diffusion kinetics equations. The results indicate that the pseudo-second order kinetic equation and intraparticle diffusion model were adequate to describe the adsorption kinetics.
\end{abstract}

Keywords: carbon nanotube, adsorption, Taguchi design, oily wastewater, $\mathrm{Pb}$ removal.

\section{Introduction}

In modern world, due to technological development, industrialization, urbanization, and agricultural activities heavy metals are discharged into water, which has become a critical issue because of their adverse effects on human

\footnotetext{
${ }^{1}$ Department of Chemical Engineering, Science and Research Branch, Islamic Azad University, Tehran, Iran

${ }^{2}$ Department of Chemical Engineering, Central Tehran Branch, Islamic

Azad University, Tehran, Iran

${ }^{3}$ Department of Chemistry, Central Tehran Branch, Islamic Azad

University, Tehran, Iran

m_otadi@iauctb.ac.ir

(C) Nansa V., Otadi M., Heydarinasab A., Amiri R., 2021
}

health and the environment [1]. Heavy metals such as $\mathrm{Cd}(\mathrm{II}), \mathrm{Cu}(\mathrm{II}), \mathrm{Pb}, \mathrm{Hg}$, and $\mathrm{Ni}(\mathrm{II})$ are toxic, nonbiodegradable, often enter in the food chain and accumulate in human body [2]. Industrial wastewaters containing heavy metals are produced from different industries include electroplating, electroless depositions, conversion-coating, anodizing-cleaning, milling, and etching. Heavy metals cause serious health effects, including reduced growth and development, cancer, organs and nervous system damage, and even death. Cadmium and lead may also cause development of autoimmunity, in which a person's immune system attacks its own cells [3].

Heavy metal removal from wastewaters can be achieved by conventional processes such as chemical precipitation, ion exchange, flocculation, membrane separation, evaporation, electrolysis, and electrochemical removal. These methods have significant disadvantages, which are, for instance, incomplete removal, high-energy requirements, and production of toxic sludge [4]. In the last decade, numerous approaches have been studied for the development of cheaper and more effective technologies. Adsorption is shown as one of the alternative treatments [5]. Basically, adsorption is a mass transfer process by which a substance is transferred from the liquid phase to the surface of a solid and becomes bound by physical and/or chemical interactions [6].

Activated carbon has been the most popular material in heavy metal removal. However, the high cost and difficult regeneration of this material makes its application less economically sound [6]. Natural bentonite [6], orange peel [7], chitosan [8,9], anaerobic granular sludge $[10,11]$ and activated carbon [7] have been tested for heavy metal removal. However, these materials usually have low adsorption capacities in as-received forms and further modifications are required to improve their applicability.

In any experimental process, the desired testing parameters are determined based on experience. However, it does not provide optimal parameter test design for a particular situation. Thus, several statistical models like factorial design have been constructed to select the proper 
testing conditions [12]. The number of experiments required for full factorial design increases geometrically by the number of parameters. Fractional factorial design method significantly reduces the time and number of experiments. However, the fractional design might not contain the best design parameters. Taguchi design can simplify the procedure by expending the application of the traditional experimental designs to the use of orthogonal array. This method is a simple, efficient and systematic approach to optimize designs for performance, quality and cost. Taguchi method has led to limited number of applications in a number of industries worldwide [13].

In this study, we focused on adsorption of $\mathrm{Pb}$ ions in aqueous solution using anthraquinone modified carbon nanotube (ACNT) based on Taguchi method under various testing conditions. The effects of sorbent type and dosage, contact time, $\mathrm{pH}$ and temperature on the adsorption were considered. Furthermore, the analysis of variances was employed to investigate the optimum test parameters for better removal.

\section{Experimental}

\subsection{Theory}

Taguchi orthogonal design establishes systemic, simple and cost-effective methodology for the optimization of parameters with a set of well-defined experiments. For this study, an L16 orthogonal array was used to design experiments with five 4-level factors, including: $\mathrm{pH}$, temperature, adsorbent type, adsorbent dosage, and contact time. Factors are designated in the column in random order. The used level setting values of the main factors (A-E) and the L16 matrix employed to assign the considered factors are shown in Table 1. Data analysis was performed by use of the statistical analysis of variance (ANOVA) method. The optimal conditions were determined by combining the optimal levels of the factors. All calculations were analyzed using Minitab 16 software.

Table 1 shows five factors: $\mathrm{pH}$ value (A), adsorbent dosage (B), adsorbent type (C), contact type (D), and removal temperature (E) and four levels used in this experiment. This design requires sixteen experiments and all experiments were carried out in triplicate under the same conditions and the average results were taken. The interaction between main factors was neglected. The signal to noise ratio $(\mathrm{S} / \mathrm{N})$ were computed for wear rate in each of the 16 trial conditions.

In order to obtain the adsorption capacity $(q)$, the amount of ions adsorbed per mass unit of adsorbent $(\mathrm{mg} / \mathrm{g})$ was calculated by the following formula:

$$
q_{e}=\frac{\left(C_{i}-C_{e}\right)}{m} V
$$

where $C_{i}$ and $C_{e}$ are the initial and the equilibrium concentrations, respectively, $\mathrm{mg} / \mathrm{g} ; m$ is the weight of the adsorbent, $\mathrm{g} ; V$ is the solution volume, 1 .

The removal efficiency $(R, \%)$ of the adsorbent was calculated by formula (2):

$$
R=\left(\frac{C_{i}-C_{e}}{C_{i}}\right) \cdot 100 \%
$$

The linear pseudo-first-order equation is represented by

$$
\frac{d q}{d t}=K_{a d}\left(q_{e}-q_{t}\right)
$$

where $q_{t}$ is the amount of metal adsorbed at time $t, \mathrm{mg} / \mathrm{g}$; $q_{e}$ is the amount of metal adsorbed at equilibrium, $\mathrm{mg} / \mathrm{g} ; t$ is time, $\min ; K_{a d}$ is the rate constant of the Lagergren pseudo-first order adsorption process.

The integrated rate law, after applying the initial condition of $q_{t}=0$ at $t=0$, is

$$
\ln \left(q_{e} q_{t}\right)=\ln q_{e}-\frac{k_{1}}{2.303} t
$$

where $k_{1}$ is the pseudo-first order adsorption rate constant, $\min ^{-1}$. Plot of $\ln \left(q_{e}-q_{t}\right) v s$. $t$ gives a straight line for the first-order kinetics, which allows computation of the adsorption rate constant $K_{a d}$.

In some cases the pseudo-second order equation is given by:

$$
\frac{d q}{d t}=k_{2}\left(q_{e}-q_{t}\right)
$$

\begin{tabular}{|c|c|c|c|c|c|}
\hline \multirow{2}{*}{ Factor } & \multirow{2}{*}{ Array } & \multicolumn{4}{|c|}{ Level } \\
\hline & & 1 & 2 & 3 & 4 \\
\hline $\mathrm{pH}$ & $\mathrm{A}$ & 4.0 & 5.0 & 6.0 & 7.0 \\
\hline Adsorbent dose, $\mathrm{mg}$ & $\mathrm{B}$ & 10 & 20 & 50 & 100 \\
\hline Adsorbent type & $\mathrm{C}$ & $\begin{array}{l}\text { Single wall } \\
\text { CNT }\end{array}$ & $\begin{array}{l}\text { Graphen } \\
\text { oxide }\end{array}$ & $\begin{array}{c}\text { 2,6 anthraquinone modified } \\
\text { CNT }\end{array}$ & $\begin{array}{c}\text { 1,4 anthraquinone modified } \\
\text { CNT }\end{array}$ \\
\hline Contact time, $\min$ & $\mathrm{D}$ & 30 & 60 & 90 & 120 \\
\hline Temperature, $\mathrm{K}$ & $\mathrm{E}$ & 303 & 323 & 333 & 343 \\
\hline
\end{tabular}

Table 1

Factors and their levels applied in the Taguchi experimental design for lead removal 
The integrated linear pseudo-second order equation law can be expressed as:

$$
\frac{t}{q_{t}}=\frac{1}{k_{2} q_{e}^{2}}-\frac{1}{q_{e}}
$$

where $k_{2}$ is the adsorption rate constant of the pseudosecond order, $\mathrm{g} /(\mathrm{mg} \cdot \mathrm{min})$.

The Langmuir equation is expressed as follows:

$$
q_{e}=\frac{q_{e} K_{L} C_{e}}{1+K_{L} C_{e}}
$$

where $q_{e}$ is the equilibrium adsorption capacity, $\mathrm{mg} / \mathrm{g} ; C_{e}$ is the final equilibrium concentration, $\mathrm{mg} / \mathrm{l} ; K_{L}$ is the monolayer adsorption capacity related to the affinity of the binding sites and indicates the bond energy of the adsorption reaction between metal and material, $\mathrm{mg} / \mathrm{g}$ [14].

The Freundlich equation is commonly used to describe the adsorption characteristics for the heterogeneous surface. The equation is commonly represented by:

$$
\ln q_{e}=\ln K_{F}=\frac{1}{n} \ln C_{e}
$$

where $K_{F}$ and $1 / n$ are the Freundlich constants, indicating the adsorption capacity and the adsorption intensity, respectively.

\subsection{Experimental Procedure}

Under continuous stirring, $0.5 \mathrm{~g}$ of $\mathrm{SOCl}_{2}$ was added drop by drop to $0.5 \mathrm{~g}$ of multiwall carbon nanotubes (MWCNTs-COOH). After half-an-hour stirring, the precipitate was isolated by magnetic force. The suspension was refluxed under nitrogen flow for $48 \mathrm{~h}$. After the reaction was completed, the products were filtered under vacuum. Then the mixture was washed with THF and refluxed with $p$-naphthol benzein in dimethylformamide. After the reaction was completed, the products and dimethylformamide were sonicated. The resulted product was transferred into the ice bath $(277 \mathrm{~K})$. To synthesis the diazonium ion, $0.05 \mathrm{~g}$ of 2,6 diaminoanthraquinone were suspended in $4 \mathrm{ml}$ of $50 \%(\mathrm{v} / \mathrm{v})$ $\mathrm{HCl}$ :distilled water solution and sonicated for $3 \mathrm{~min}$. Then a cold solution of $\mathrm{NaNO}_{2}$ was added. To conjugate diazonium ion to the MWCNTs, this ion and DMF were added to MWCNTs. Then the mixture was stirred until reaction ended.

Batch adsorption tests were performed to obtain equilibrium isotherms. Known volumes of metal ions stock solution were pipetted into glass bottles containing $2.0 \mathrm{mg}$ of sorbent in $20 \mathrm{ml}$ blank solution $(1.6 \mathrm{ml}$ blank oil $+18.4 \mathrm{ml} 0.2 \mathrm{M} \mathrm{NaCl}, \mathrm{pH}=6.0$ ) to give concentrations ranging from 1 to $100 \mathrm{mgl}^{-1}$ for lead. The resulting solution was then stirred at $1200 \mathrm{rpm}$ and $333 \mathrm{~K}$ in order to study the adsorption process. Preliminary experiments showed that 60 min were sufficient for adsorption of $\mathrm{Pb}$ ions onto ACNT. After 10 min of centrifugation, the metal ion concentration in the supernatant was determined by atomic absorption spectrometry (at the wavelength of $217 \mathrm{~nm}$, lamp current $8 \mathrm{~mA}$, slit width $0.7 \mathrm{~nm}$, acetylene as fuel, air as support and flame stoichiometry is oxidizing).

\subsection{Materials and Instruments}

All solutions were prepared in Millipore milli Q high purity water. The reactant and all other chemicals used in this study were of analytical grade and supplied by Sigma-Aldrich (Germany). Metal stock solutions of $1000 \mathrm{mg} / \mathrm{l}$ were prepared by dissolving appropriate amounts of $\mathrm{Pb}$ nitrate salt in deionized water. The $\mathrm{pH}$ was adjusted using $0.1 \mathrm{M} \mathrm{NaOH}$ or $0.1 \mathrm{M} \mathrm{HNO}_{3}$.

Concentration of the metal ion solutions was performed by using a Perkin Elmer model Atomic Absorption Spectrotometer 2380 (USA). An infrared spectrum was obtained using a Fourier transform infrared spectrometer (FT-IR, Nichlet, Nexs 870) and scanning electron microscopy (SEM, Leo 440i). The $\mathrm{pH}$ measurements of metal ions and buffer solutions were carried out by an Orion 420. All reagents used were of analytical grade. Laboratory glassware was kept overnight in a $10 \%(\mathrm{v} / \mathrm{v}) \mathrm{HNO}_{3}$ solution and then rinsed with deionized double distilled water. The nitrate salt of $\mathrm{Pb}$ analytical grade (Merck) was used without further purification. More dilute solutions were prepared daily from $1000 \mathrm{mg} \cdot \mathrm{l}^{-1}$ stock solutions.

\section{Results and Discussion}

\subsection{Characterization}

The characterization of anthraquinone modified carbon nanotube was accomplished by FTIR spectroscopy and SEM images. FTIR analysis was carried out in order to identify the different functional groups which were responsible for adsorption process. The peaks appearing in the FTIR spectrum were assigned to various functional groups according to their respective wave numbers as reported in literatures. The FTIR spectra of the ACNTs before adsorption are shown in Fig. 1.

The broad absorption band in the region of 3450 $3200 \mathrm{~cm}^{-1}$ was attributed to the stretching of O-H group due to inter- and intramolecular hydrogen bonding. Peaks at around $1600 \mathrm{~cm}^{-1}$ on both graphs correspond to $\mathrm{O}-\mathrm{H}$ stretching. The FTIR also revealed the presence of intense peak at $1675 \mathrm{~cm}^{-1}$ which are assigned to the $\mathrm{C}=\mathrm{O}$ stretching mode of the anthraquinone quinonyl (AQ) groups. The less intense peak centered at 2818 and $3060 \mathrm{~cm}^{-1}$ was assigned to the stretching mode of the aromatic ring. The band at $1430 \mathrm{~cm}^{-1}$ is assigned to $\mathrm{C}-\mathrm{N}$ stretching while two other distinct bands at 1690 and $1575 \mathrm{~cm}^{-1}$ are located in the zone related to the $(-\mathrm{CONH}-)$, corresponding to the $(\mathrm{C}=\mathrm{O})$ stretching band (amide I) and to the $(\mathrm{N}-\mathrm{H})$ bending vibration (amide II) band, respectively. 


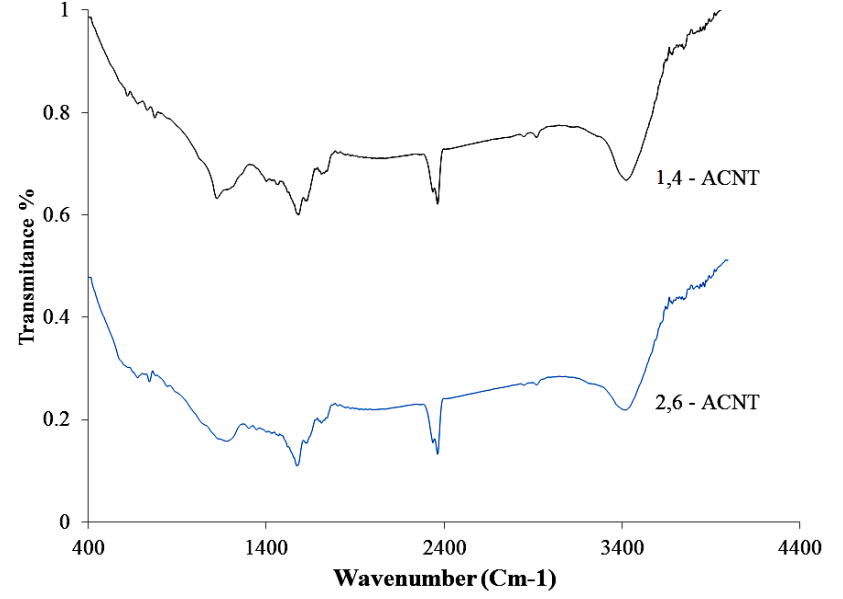

Fig. 1. FTIR spectra of $1,4 \mathrm{ACNT}$ (a) and $2,6 \mathrm{ACNT}$ (b)

This indicates the presence of amide bond formed between $\mathrm{AQ}$ and $\mathrm{C}_{6} \mathrm{H}_{4} \mathrm{CH}_{2} \mathrm{NH}$-linker. Characteristic $\mathrm{N}-\mathrm{H}$

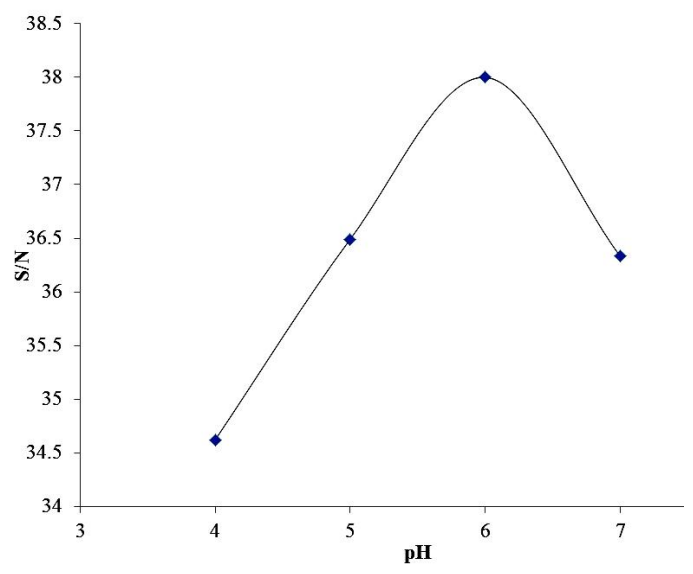

a)

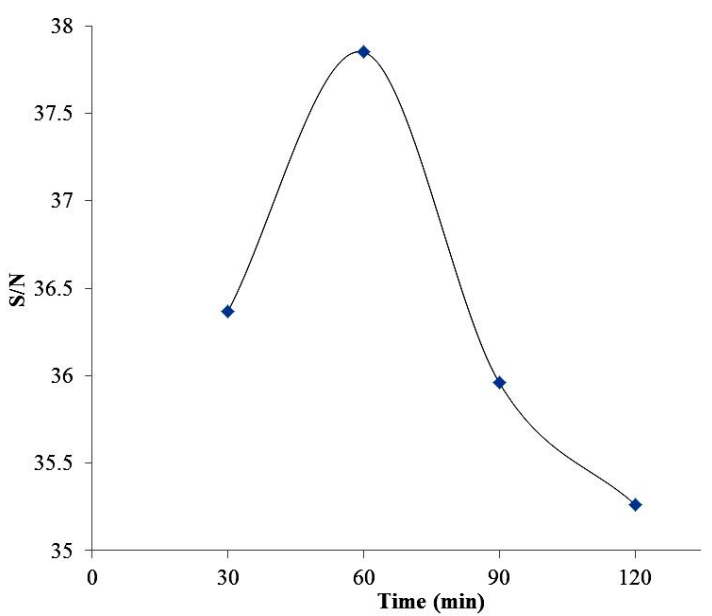

c) stretching band located at $3320 \mathrm{~cm}^{-1}$ and out of plane $\mathrm{N}-\mathrm{H}$ wagging corresponds to 692 and $800 \mathrm{~cm}^{-1}$. The assignment of other peaks can be found elsewhere [15].

\subsection{Taguchi Design}

Sixteen different sets of experiments were performed using Taguchi methodology (L16, the L and the subscript (16) equal the Latin square and the number of experimental runs, respectively) for process optimization. Taguchi method is to evaluate the optimal experimental conditions for measurement of metal removal. "Larger is Better" analysis was performed to find the optimum conditions for various factors and their performance to enhance lead removal yield. Taguchi design suggests that the optimum condition for the maximum removal is the combination of $\mathrm{A} 3 \mathrm{~B} 3 \mathrm{C} 2 \mathrm{D} 2 \mathrm{E} 1$ levels of the respective factors. It is evident from Fig $2 \mathrm{a}$ that $\mathrm{pH}$ (factor $\mathrm{A}$ ) has the greatest increasing effect on the removal percent.

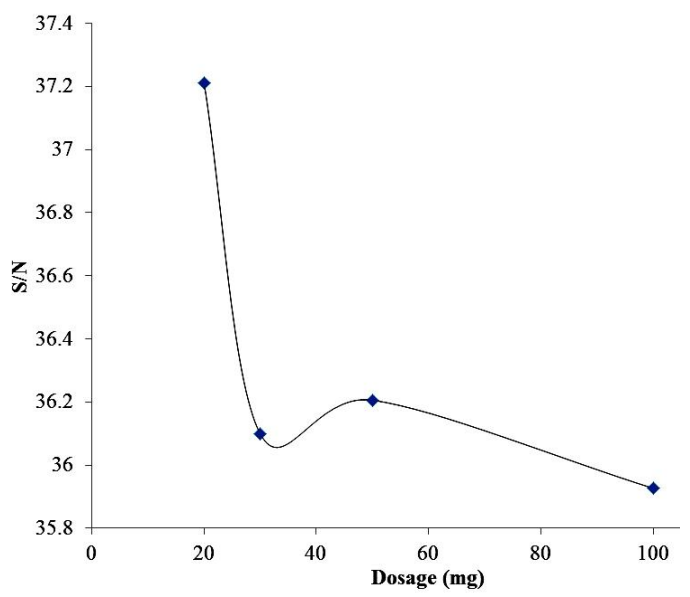

b)

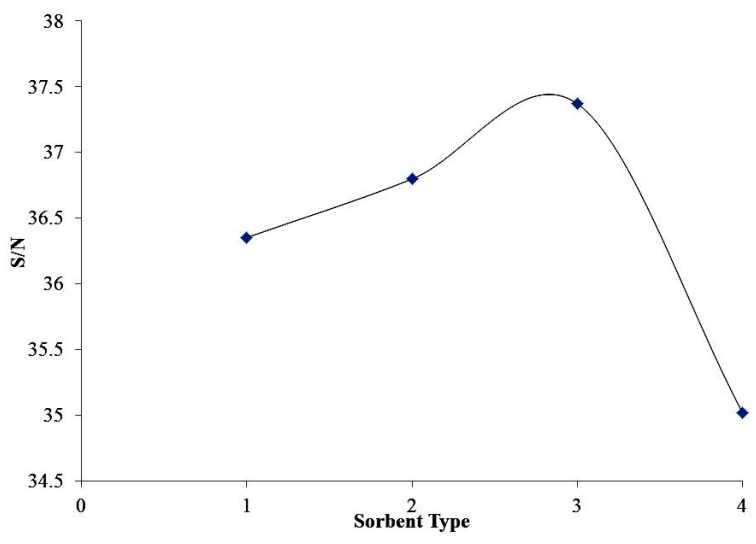

d)

Fig. 2. Effects of $\mathrm{pH}$ (a); sorbent dosages (b); contact time (c), and sorbent type (d) on the S/N ratio 
The removal efficiency values are given in Table 2. According to the combinations of the selected factors, the metal removal yield ranged from 38.2 to $97.5 \%$. The results suggest that the effect of one factor to get the most removal of lead depends on the levels of the other factors. Analysis of data using the ANOVA method for determining of significant factors on lead removal was carried out and the results are illustrated in an ANOVA Table after pooling-up technique (Table 3). On the basis of the pooling results, $\mathrm{pH}$, adsorbent type and removal temperature were the most significant factors for removal experiments, respectively. The results indicate that the yield of expected lead removal under the optimum conditions was calculated as $96.87 \%$.

Table 2

L16 orthogonal array of Taguchi experimental design for optimizing the removal of lead

\begin{tabular}{|c|c|c|c|c|c|c|c|c|c|}
\hline Run & A & B & C & D & E & Result1 & Result2 & Result3 & Mean \\
\hline 1 & 1 & 1 & 1 & 1 & 1 & 58.1 & 55.9 & 57.6 & 57.2 \\
\hline 2 & 1 & 2 & 2 & 2 & 2 & 70.4 & 71.1 & 69.0 & 70.2 \\
\hline 3 & 1 & 3 & 3 & 3 & 3 & 53.2 & 53.8 & 55.1 & 54.0 \\
\hline 4 & 1 & 4 & 4 & 4 & 4 & 38.6 & 38.8 & 38.2 & 38.2 \\
\hline 5 & 2 & 1 & 2 & 3 & 4 & 73.8 & 71.6 & 73.0 & 72.8 \\
\hline 6 & 2 & 2 & 1 & 4 & 3 & 52.9 & 53.8 & 53.4 & 53.4 \\
\hline 7 & 2 & 3 & 4 & 1 & 2 & 60.7 & 63.2 & 61.6 & 61.8 \\
\hline 8 & 2 & 4 & 3 & 2 & 1 & 83.8 & 82.8 & 80.7 & 82.4 \\
\hline 9 & 3 & 1 & 3 & 4 & 2 & 93.6 & 94.5 & 93.3 & 94.0 \\
\hline 10 & 3 & 2 & 4 & 3 & 1 & 62.4 & 63.1 & 63.3 & 62.9 \\
\hline 11 & 3 & 3 & 1 & 2 & 4 & 91.3 & 94.0 & 92.6 & 92.6 \\
\hline 12 & 3 & 4 & 2 & 1 & 3 & 74.6 & 73.7 & 73.9 & 74.1 \\
\hline 13 & 4 & 1 & 4 & 2 & 3 & 69.1 & 66.3 & 68.4 & 68.1 \\
\hline 14 & 4 & 2 & 3 & 1 & 4 & 71.4 & 71.8 & 69.9 & 71.0 \\
\hline 15 & 4 & 3 & 2 & 4 & 1 & 59.0 & 56.8 & 58.5 & 57.9 \\
\hline 16 & 4 & 4 & 1 & 3 & 2 & 63.5 & 61.9 & 63.2 & 62.9 \\
\hline
\end{tabular}

Table 3

Analysis of variance (ANOVA) $(P=95 \%)$

\begin{tabular}{|c|c|c|c|c|}
\hline Parameter & DF & SS & MS & F \\
\hline A & 2 & 1120.64 & 560.32 & 9.0 \\
\hline B & 2 & 198.56 & 99.28 & 1.6 \\
\hline C & 2 & 401.2 & 200.6 & 3.2 \\
\hline D & 2 & 721.2 & 360.6 & 5.8 \\
\hline E & 2 & 404.4 & 202.2 & 3.2 \\
\hline Error & 5 & 311.115 & 8.408 & - \\
\hline Total & 15 & 3157.115 & - & - \\
\hline
\end{tabular}

\subsection{Optimization}

Fig. 2a shows the effects of $\mathrm{pH}$ on the adsorption of $\mathrm{Pb}$ by ACNT. The adsorption of metal ions from aqueous solutions depends on the solution $\mathrm{pH}$ because it affects adsorbent surface charge, degree of ionization, solubility of the metal ions, concentration of the counter ions on the functional groups of the adsorbent, and the speciation of adsorbates. At $\mathrm{pH}=2$, the adsorption efficiency of metal ions by ACNT was nearly zero, in an acidic solution $(\mathrm{pH}>3)$ a relatively high concentration of protons strongly competed with cationic lead ions and thus, the adsorption of cations significantly decreased. With an increasing $\mathrm{pH}$, the electrostatic repulsion between the surface and metal ions was reduced and this reduction enhanced the adsorption capacity. The figure also indicates that $\mathrm{Pb}$ adsorption decreased when the solution $\mathrm{pH}$ exceeded 6 and its adsorption was completely inhibited at $\mathrm{pH}=9$. At alkaline conditions $(\mathrm{pH}>>7)$, metal ions precipitate as $\mathrm{PbO}(\mathrm{s})$.

The impact of adsorbent dose on the adsorption of $\mathrm{Pb}$ is shown in Fig. 2b. According to [15], at lower adsorbent dose the removal percentage was higher due to larger surface area of adsorbent being available for adsorption.

Fig. 2c shows the effect of contact time on sorption of $\mathrm{Pb}$ ions. In order to establish the equilibration time for the maximum adsorption capacity, the adsorption capacities of $\mathrm{Pb}$ on adsorbent were measured as a function of time. This result revealed that adsorption of $\mathrm{Pb}$ was fast and the equilibrium was achieved after $60 \mathrm{~min}$ of contact 
time. It is known that the adsorption process could be controlled by various mechanisms such as mass transfer, diffusion, diffusion, chemical reactions, and particle diffusion [16]. The plot of lead removal as a function of time is single, smooth, and continuous, suggesting the possible formation of monolayer coverage of $\mathrm{Pb}$ ions at the outer surface of adsorbent.

The type of adsorbents is one of important factors affecting the adsorption process as it influences the surface area of adsorbent. Fig. $2 \mathrm{~d}$ shows the variation of $\mathrm{Pb}$ removal as a function of adsorbent type. The higher removal of lead with ACNT adsorbent was attributed to the fact that smaller particles had a larger external surface area compared to larger particles; hence more binding sites were exposed on the surface, thus, leading to higher adsorption capacity since adsorption is a surface process.

Adsorption often involves a chemical reaction between functional groups present on the adsorbent surface and the adsorbate, system parameters such as temperature, contact time and $\mathrm{pH}$. In the case of adsorption preceded by diffusion through a boundary, the kinetics in most cases follows the pseudo-first order equation of
Lagergren. In order to clarify the adsorption interactions, the first- and second-order models were used to identify the rate and kinetics of adsorption of $\mathrm{Pb}$ on the ACNT adsorbent. The kinetic parameters for lead adsorption are given in Table 4.

Based on the obtained correlation coefficients, the pseudo-second-order equation was the model that yielded the best fit for the experimental kinetic data. This suggests that chemical sorption is the rate-limiting step of the adsorption mechanism and that mass transfer is not involved in the solution [17].

In this study, the adsorption mechanisms were analyzed by two (Langmuir and Freundlich) two-parameter isotherm models, which are commonly used to describe experimental results in a wide range of concentrations. The Langmuir isotherm model was originally developed to describe the gas solid phase adsorption. The Langmuir adsorption model assumes that all adsorption sites are energetically identical, and adsorption occurs on a structurally homogeneous adsorbent. Fig. 3a shows that the plot of $1 / q_{e} v s .1 / C_{e}$ dives a straight line suggesting the applicability of the Langmuir model.

Table 4

Kinetic parameters for lead adsorption

\begin{tabular}{|l|c|c|c|}
\hline \multicolumn{1}{|c|}{ Kinetic models } & $R^{2}$ & $q_{e}, \mathrm{mg} / \mathrm{g}$ & $K_{i}$ \\
\hline Pseudo-first order & 0.9287 & 0.23062 & 0.1117 \\
\cline { 3 - 4 }$/ d t=k_{a d}\left(q_{e}-q_{t}\right)$ & 0.7387 & 0.30472 & 0.1101 \\
\hline Pseudo-second order & 0.9934 & 0.57688 & 1.0006 \\
$d q / d t=k_{2}\left(q_{e}-q t\right)^{2}$ & 0.9902 & 0.68353 & 0.5699 \\
\hline \multirow{3}{*}{ Intermolecular diffusion } & & Molar concentration & $K_{d i f}, \mathrm{mg}^{\cdot \mathrm{g}^{-1}} \cdot \mathrm{t}^{-0.5}$ \\
\cline { 2 - 4 } & 0.9566 & 0.4469 & 0.0193 \\
\cline { 2 - 4 } & 0.8065 & 0.5776 & 0.0027 \\
\hline
\end{tabular}

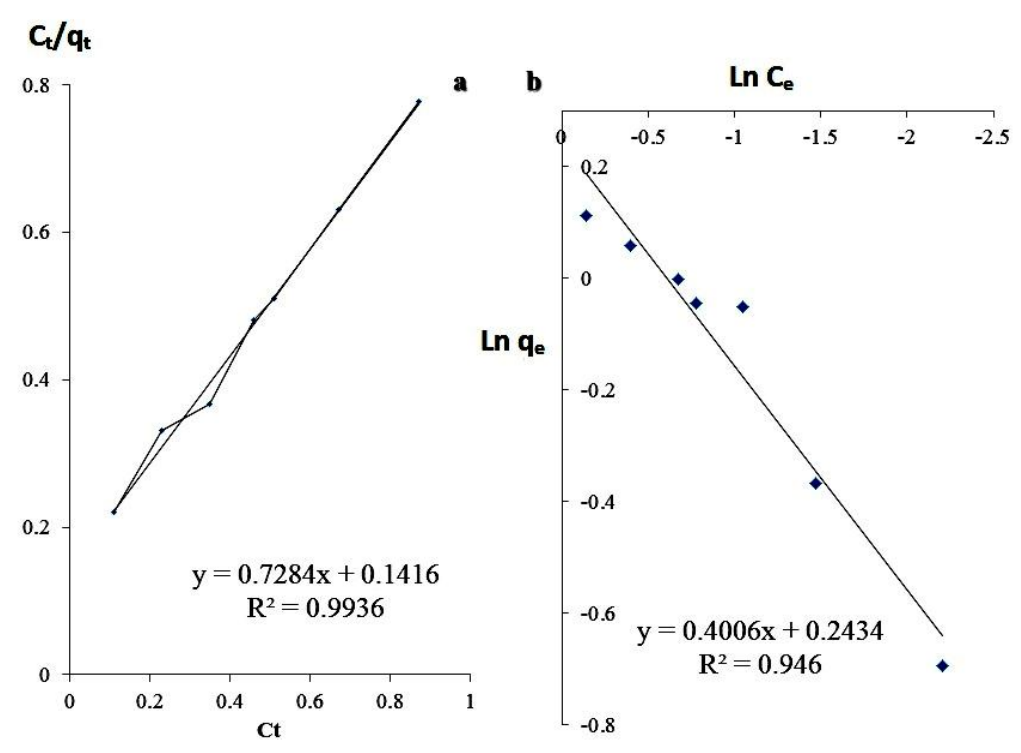

Fig. 3. Langmuir (a) and Freundlich (b) models 
The function has an asymptotic maximum as pressure increases without bound. As the temperature increases, the constants $k$ and $\mathrm{n}$ change to reflect the empirical observation that the quantity adsorbed rises more slowly and higher pressures are required to saturate the surface. Fig. 3b shows the applicability of Freundlich equation toward the adsorption of $\mathrm{Pb}$ ions (Table 5).

The equilibrium adsorption isotherm is fundamental in describing the interactive behavior between lead ions and ACNT. For the adsorption isotherm studies, the initial metal ion concentrations were in the range of $10-100 \mathrm{mg} / \mathrm{l}$.

The stability and reproducibility of the adsorbent were investigated by regeneration experiments. This procedure is necessary to restore the original adsorption capacity of the adsorbent, and it also enables recovering valuable metals from wastewater streams. The regeneration process was studied in $\mathrm{Pb}$ solutions. At first, adsorbents were loaded by mixing $0.002 \mathrm{~g}$ of the adsorbent with 0.0101 of $0.001-0.06 \mathrm{~g}$ metal salt in blank solution. After attaining equilibrium $(\mathrm{pH}=6.0, t=60 \mathrm{~min}$, $T=333 \mathrm{~K}$ ) the spent adsorbent was separated by centrifuge. Metal ions were eluted using solvents that are shown in Table 6.

The metal ion absorption was used as adsorbent parameter. After the third cycle of regeneration, the adsorption capacities of ACNTs still remained the same. After identifying the adsorption solvent, solvent volume was optimized by using a set of volumes from 2.0 to 20.0 ml. Results are shown in Fig. 4.

Table 5

Isotherm constants of ACNT for $\mathrm{Pb}$

\begin{tabular}{|c|c|c|}
\hline \multirow{2}{*}{ Isotherm model } & \multicolumn{2}{|c|}{ Parameters } \\
\cline { 2 - 3 } & $k, 1 \cdot \mathrm{mg}^{-1}$ & $q_{\max }=1.3724 \mathrm{mg} \cdot \mathrm{g}^{-1}$ \\
\hline Langmuir & 5.1441 & $n=2.5$ \\
\hline Freundlich & 1.2756 & \\
\hline
\end{tabular}

Table 6

Solvents for lead desorption from adsorbent

\begin{tabular}{|c|c|}
\hline Solvent number & Solvent composition \\
\hline 1 & $10 \mathrm{ml}$ EDTA $(0.1 \mathrm{M}) ; \mathrm{pH}=4$ \\
\hline 2 & $10 \mathrm{ml}$ EDTA $(0.2 \mathrm{M}) ; \mathrm{pH}=4$ \\
\hline 3 & $10 \mathrm{ml}$ EDTA $(0.5 \mathrm{M}) ; \mathrm{pH}=4$ \\
\hline 4 & $10 \mathrm{ml}$ aqueous solution; $\mathrm{pH}=1.5$ \\
\hline 5 & $10 \mathrm{ml}$ aqueous solution; $\mathrm{pH}=2.0$ \\
\hline 6 & $10 \mathrm{ml}$ aqueous solution; $\mathrm{pH}=2.5$ \\
\hline
\end{tabular}


Fig. 4. Effects of desorption solvent type (a) and desorption solvent volume (b) 


\subsection{Application to Real Samples}

To investigate the applicability of the recommended procedure, a series of oil industry wastewaters were analyzed by developed method. The results are given in Table 7. The proposed removal method in some wastewater samples was applied successfully. Chalos, Shiraz and Isfahan petrochemical industries samples were investigated as samples with complex matrices. As can be seen from the results in Table 7 , the metal ions were quantitatively removed from the water samples by the proposed procedure.

Table 7

The removal yield of ACNT

\begin{tabular}{|c|c|c|c|}
\hline Sample & Pb added, $\mathrm{mg} / \mathrm{l} ; n=3$ & Pb found, $\mathrm{mg} / \mathrm{l} ; n=3$ & Removal recovery, $\%$ \\
\hline \multirow{3}{*}{$\begin{array}{c}\text { Chalos petrochemical } \\
\text { industry }\end{array}$} & - & $0.04 \pm 8.67$ & - \\
\cline { 2 - 4 } & 1.0 & $0.03 \pm 9.61$ & 97 \\
\cline { 2 - 4 } & 2.0 & $0.03 \pm 10.64$ & 102 \\
\hline \multirow{3}{*}{$\begin{array}{c}\text { Isfahan petrochemical } \\
\text { industry }\end{array}$} & 3.0 & $0.05 \pm 11.69$ & - \\
\cline { 2 - 4 } & - & $0.04 \pm 7.47$ & 98 \\
\cline { 2 - 4 } & 1.0 & $0.05 \pm 8.39$ & 96 \\
\hline \multirow{3}{*}{$\begin{array}{c}\text { Shiraz petrochemical } \\
\text { industry }\end{array}$} & 2.0 & $0.03 \pm 9.41$ & - \\
\cline { 2 - 4 } & 3.0 & $0.03 \pm 10.56$ & 98 \\
\cline { 2 - 4 } & - & $0.05 \pm 8.09$ & 98 \\
\cline { 2 - 4 } & 1.0 & $0.04 \pm 9.03$ & 100 \\
\hline
\end{tabular}

\section{Conclusions}

In this paper, the anthraquinone modified CNT adsorbent for $\mathrm{Pb}$ ions was successfully prepared using a very quick and easy method. Investigation of the equilibrium sorption was carried out at $333 \mathrm{~K}, 60 \mathrm{~min}$ contact time and $\mathrm{pH}=6.0$. The sorption data were fitted the Langmuir and Freundlich isotherms and the calculated values of the dimensionless separation factor RL from the Langmuir isotherm constants confirm favorable sorption of $\mathrm{Pb}$ onto ACNT. Adsorption process is found to follow the first-order Lagregren rate kinetics. Taguchi and ANOVA methods were applied to investigate the effects of $\mathrm{pH}$ value of aqueous solution, contact time, adsorbent type, and dose. The $\mathrm{pH}$ value of aqueous solution is the major parameter for lead removal process. The optimum test condition, at which the larger removal is obtained, has been determined to be A3B3C2D2E1 level. The kinetic study demonstrated that the kinetic mechanism for the adsorption of metal ions followed the pseudo-second order model, which provided the best correlation with the experimental data. It could be concluded that anthraquinone modified carbon nanotube is a potent and active adsorbent for removal of lead ions from its aqueous solution and industrial wastewater remediation.

\section{References}

[1] Kraus U., Wiegand J.: Sci. Total. Environ., 2006, 367, 855. https://doi.org/10.1016/j.scitotenv.2005.12.027

[2] Mohammad A., Othaman A., Hilal N.: Desalination, 2004, 168, 241. https://doi.org/10.1016/j.desal.2004.07.004

「31 Coca J., Gutiérrez G., Benito J.: Treatment of Oily Wastewater. [in:] Coca-Prados J., Gutiérrez-Cervelló G. (Eds.), Water
Purification and Management. NATO Science for Peace and Security Series C: Environmental Security. Springer, Dordrecht 2011. https://doi.org/10.1007/978-90-481-9775-0 1

[4] Bayramoglu G., Altintas B., Arica M.: Chem. Eng. J., 2009, 152, 339. https://doi.org/10.1016/j.cej.2009.04.051

[5] Pyrzysnska K., Bystrzejewski M.: Colloid Surface A, 2010, 362, 102. https://doi.org/10.1016/j.colsurfa.2010.03.047

[6] Babel S., Kurniawan T.: J. Hazard. Mater., 2003, 97, 219. https://doi.org/10.1016/S0304-3894(02)00263-7

[7] Ajmal M., Rao R., Ahmad R., Ahmad J.: J. Hazard. Mater., 2000, 79, 117. https://doi.org/10.1016/S0304-3894(00)00234-X [8] Zhang L., Zeng L., Cheng Z.: J. Mol. Liq., 2016, 214, 175. https://doi.org/10.1016/j.molliq.2015.12.013

[9] Bhatnagar A., Sillanpää M.: Adv. Colloid Interface Sci., 2009, 152, 26. https://doi.org/10.1016/j.cis.2009.09.003

[10] van Hullebusch E., Peerbolte A., Zandvoort M., Lens P.:

Chemosphere, 2005, 58, 493.

https://doi.org/10.1016/j.chemosphere.2004.09.017

[11] Cai J., Liu G., Tuo Y. et al.: J. Appl. Sci., 2014, 14, 833.

https://doi.org/10.3923/jas.2014.833.837

[12] Ghosh S., Swaminathan T.: Chem. Biochem. Eng. Q., 2003, $17,319$.

[13] Taguchi E., Gorsuch G., Lems K., Rosszell R.: Reading in a Foreign Language, 2016, 28, 101.

[14] Farghalia A., Bahgatb M., Enaiet Allaha A., Khedra M.: Beni-

Suef Univ. J. Basic Appl. Sci., 2013, 2, 61.

https://doi.org/10.1016/j.bjbas.2013.01.001

[15] Barathi P., Kumar A.: Electroanalysis, 2014, 26, 1.

https://doi.org/10.1002/elan.201400250

[16] Hokkanen S., Repo E., Suopajärvi T. et al.: Cellulose, 2014,

21, 1471. https://doi.org/10.1007/s10570-014-0240-4

[17] Robati M.: J. Nanostruct. Chem., 2013, 3, 55.

https://doi.org/10.1186/2193-8865-3-55

Received: March 13, 2019 / Revised: April 01, 2019 / Accepted: April 30, 2019 


\section{АДСОРБЦІЯ ЙОНІВ РЬ 3 ОЛИВНИХ СТІЧНИХ ВОД ЗА ДОПОМОГОЮ КАРБОНОВӦ̈ НАНОТРУБКИ, МОДИФІКОВАНОЇ АНТРАХІНОНОМ}

Анотація. Досліджено адсорбиійні властивості модифікованої антрахіноном карбонової нанотрубки (АКТ) в оливних стічних водах, що містять йони $\mathrm{Pb}$. Модифіковані адсорбенти були охарактеризовані за допомогою Фур'є спектроскопї та скануючої електронної мікроскопії. Дослідження адсорбиії та регенерачії проводилися в пакетному режимі, використовуючи ортогональний масив Taguchi (L16) для оптимізаиії експериментальних пробігів. Контрольованими чинниками були: рН розчину (A); дозування адсорбенту (B); тип адсорбенту (C); час контакту (D); температура $(F)$.
Вплив кожного чинника на ефективність видалення металів з водного розчину вивчався на чотирьох рівнях. 3 а допомогою атомно-абсорбиійного спектрометра визначені конщентрації йонів металів. Встановлено, щзо повне адсорбиійне видалення йонів свинцю має місие за $C_{0}=10$ мг:л ${ }^{-1}$, $T=338 \mathrm{~K}, \mathrm{pH}=6, m=0,020$ мг $i t=60$ хв. Визначено, щяо для моделювання ізотерм адсорбиї репрезентативною є модель Ленгмюра. Кінетика адсорбиї свинию АКТ моделювалася за допомогою рівнянь псевдо-периого порядку, псевдо-другого порядку та внутрішньодифузійної кінетики. Встановлено, що кінетичне рівняння псевдо-другого порядку та модель внутрішньої дифузї $\epsilon$ адекватними для опису кінетики адсорбиіï.

Ключові слова: вуглецева нанотрубка, адсорбиія, метод Тагучі, оливні стічні води, видалення $\mathrm{Pb}$. 